Arq. Bras. Med. Vet. Zootec., v.72, n.3, p.769-777, 2020

\title{
3D printing of canine hip dysplasia: anatomic models and radiographs
}

\author{
[Impressão 3D da displasia coxofemoral canina: modelos anatômicos e radiografias]
}

\author{
R.Y.G. Nunez ${ }^{1}$, L.K. Albuquerque ${ }^{1}$, R.C.R. Pereira ${ }^{2}$, \\ R.P.M. Silva ${ }^{2}$, P.F. Peruquetti ${ }^{1}$, Y.K. Carvalho ${ }^{1 *}$
}

${ }^{1}$ Aluno de pós-graduação - Universidade Federal do Acre - Rio Branco, AC

${ }^{2}$ Centro de Ciências da Saúde e do Desporto - Universidade Federal do Acre - Rio Branco, AC

\begin{abstract}
Canine Hip Dysplasia (CHD) is a highly prevalent articular pathological condition. In this sense, radiography becomes an important diagnostic method to determine the presence and severity of the disease. The objective was to create $3 \mathrm{D}$ models and their respective radiographs representing the CHD (3D AMCHD). The research was carried out in the Laboratory of 3D Educational Technologies of UFAC, under no. 23107.007273/2017-49 (CEUA/UFAC). A canine skeleton (hip bone, femurs and patellae) was used without anatomical deformities compatible with DCF (pelvis, femurs and patella), which were scanned in order to obtain the files of the base model. In these files the deformations representing the different degrees of CHD were performed. Subsequently, the 3D AMCHD files were printed, mounted and X-rayed. The 3D AMCHD represented the bone deformations of the different degrees of CHD. In the radiographs of the $3 \mathrm{D}$ AMCHD it was possible to observe and determine each of the bones that constituted the hip joints. This allowed to reproduce the correct positioning to represent the CHD diagnosis and establish the precise points to determine the Norberg angle. In this way, it was evidenced that the 3D AMCHD can be a possible tool to be used in the Teaching of Veterinary Medicine.
\end{abstract}

Keywords: rapid prototyping, radiology, diagnostic imaging, Norberg angle, 3D modeling

\section{RESUMO}

A displasia coxofemoral canina (DCF) é uma condição patológica articular de grande prevalência. Nesse sentido, a radiografia torna-se um método de diagnóstico importante para determinar a presença e a gravidade da doença. O objetivo do presente trabalho foi criar modelos $3 D$ e suas respectivas radiografias representando a DCF (MADCF $3 D)$. A pesquisa foi realizada no Laboratório de Tecnologias Educacionais 3D da UFAC, sob o $n^{o}$. 23107.007273/2017-49 (Ceua/Ufac). Foram utilizados esqueletos caninos (pelve, fêmures e patelas) sem deformidades anatômicas compatíveis com a DCF, os quais foram digitalizados a fim de se obterem os arquivos do modelo base. Nesses arquivos foram realizadas as deformações que representavam os diferentes graus da DCF. Posteriormente, os arquivos dos MADCF $3 D$ foram impressos, montados e radiografados. Os MADCF $3 D$ representaram as deformações ósseas dos diferentes graus da DCF. Nas radiografias dos MADCF 3D, foi possível observar e determinar cada um dos ossos que constituíam as articulações coxofemorais. Isso permitiu reproduzir o posicionamento correto para representação do diagnóstico DCF e estabelecer os pontos precisos para determinar o ângulo de Norberg. Dessa forma, evidenciou-se que os MADCF 3D podem ser uma possível ferramenta a ser empregada no ensino de medicina veterinária.

Palavras-chave: prototipagem rápida, radiologia, diagnóstico por imagem, ângulo de Norberg, modelagem $3 D$

Recebido em 21 de junho de 2018

Aceito em 15 de agosto de 2019

*Autor para correspondência (corresponding author)

E-mail: ykaracas@yahoo.com.br 


\section{INTRODUCTION}

Canine Hip Dysplasia (CHD) is a developmental condition that may lead to musculoskeletal disorders of the coxofemoral joint. It is characterized by the instability and incongruity of the involved joint structures, causing dislocation and/or osteoarthritis in one or both joints. It is one of the most prevalent multifactorial orthopedic diseases of hereditary origin in dogs, manifesting with pain, claudication and rigidity (Soo and Worth, 2015). Radiography has been the standard procedure for assessing and quantifying the anatomopathological changes associated with CHD. Among the different methods used for precise radiographic diagnosis of the disease and its different degrees of presentation, there is the Norberg Angle and its index (Janssens et al., 2013).

Knowledge of the anatomy of the coxofemoral joint and the different degrees of manifestation of CHD are essential components in the training of the veterinarian, since it requires professionals and future professionals to recognize the stage of the disease to promote the best clinical/surgical treatment (Schachner and López, 2015). In this context, the advent of $3 \mathrm{D}$ printing enabled the teaching institutions to develop inexpensive anatomical models from the use of scanner and 3D printers, allowing students and professors to have access to training and qualification in areas that need prior planning, in addition to being able to easily produce anatomical models (Lim et al., 2016).

In an area where animal use is increasingly restricted, new alternatives to CHD training and understanding are needed (McMenamin et al., 2014). The purpose of the study was to reproduce and to create via $3 \mathrm{D}$ printing viable, reliable and representative anatomical models of each degree of the disease, trying to reproduce the bone deformations advocated by the FCI and the Norberg angle of the CHD.

\section{MATERIALS AND METHODS}

The research was developed at the Federal University of Acre (UFAC), Rio Branco, AC, Brazil, at the Laboratory of 3D Educational Technologies and was registered and approved under process number 23107.007273/2017-49 in the Ethics Committee on the Use of Animals (CEUA- UFAC). The canine skeleton (hip bone, femurs and patellae) used had no anatomical deformities compatible with DCF. The bones from the collection of the Laboratory of Animal Anatomy of UFAC were meticulously prepared and made available for scanning.

The three-dimensional scanning was performed individually with a Matter and Form 3D scanner (Matter and Form $@$, Toronto, Canada), which features the CMOS HD sensor and two lasers with scanning precision of $0.43 \mathrm{~mm}$ and capture size of $\pm 0.25 \mathrm{~mm}$. The digital files obtained were modified using the software Autodesk Meshmixer@ (Autodesk Inc., California, United States) to make anatomical changes, and deformations were performed in order to obtain the five degrees that classify the severity of CHD and respect the classification advocated by the Brazilian College of Veterinary Radiology (2016) and the criteria of evaluation of the World Canine Organization (FCI) and are based on the Norberg angle measurement (Table 1).

Table 1. Visible anatomical alterations in the different degrees of Canine Hip Dysplasia according to the classification of the World Canine Organization (FCI)

\begin{tabular}{cll}
\hline Degree & Angle & \multicolumn{1}{c}{ Visible anatomical alterations } \\
\hline 0 & $\geq 105^{\circ}$ & $\begin{array}{l}\text { Congruence. Pointed and slightly rounded craniolateral edge. Narrow and regular } \\
\text { articular space. }\end{array}$ \\
I & $<105^{\circ}$ & $\begin{array}{l}\text { Slight incongruity. Center of the femoral head is presented medially to the dorsal } \\
\text { acetabular edge. }\end{array}$ \\
II & $\geq 100^{\circ}$ & $\begin{array}{l}\text { Incongruity. Slight flattening of the craniolateral acetabular edge. Small signs of } \\
\text { osteoarthrosis of the acetabular margins or in the head and neck of the femur. } \\
\text { Evident incongruity. Signs of subluxation. Flattening of the craniolateral edge or } \\
\text { osteoarthrosis. } \\
\text { Evident dysplastic joint changes. Signs of dislocation. Flattening of the cranial } \\
\text { acetabular edge. Deformation of the femoral head. Osteoarthrosis. }\end{array}$ \\
\hline IV & $<90^{\circ}$
\end{tabular}

Adapted from (Flückiger, 2007) 
Once the deformations of each degree were achieved, the files were printed separately on a 3D Up Mini@ printer (Beijing Tiertime Technology Co. Ltd., Beijing, China), which uses the FDM (Fused Deposition Modeling) technology, using the ABS (Acrylonitrile Butadiene Styrene) thermoplastic filament with fine quality, internal fill of $99 \%$ and layer thickness of $0.2 \mathrm{~mm}$. After this step the models were assembled with the preservation of the coxofemoral joints.

All printed 3D Anatomical Models of Canine Hip Dysplasia (3D AMCHD) were subjected to radiographic testing on a General Electric digital X-ray machine model DR-F (General Electric Company(), United States), exposure of $50 \mathrm{kv}$ radiation intensity and exposure time of $6.3 \mathrm{mAs}$. Each radiographic image of the 3D AMCHD was evaluated by measuring the angles according to Norberg, using the software RadiAnt DICOM Viewer@ (2009-2017 Medixant@), Poznan, Poland).

The radiographic positioning adopted was the one standardized by the World Canine Organization or "Positioning 1" of the radiographic procedure to evaluate the $\mathrm{CHD}$. The procedure consisted of: dorsal decubitus, extended pelvic limbs parallel to each other and to the vertebral column; femoral-tibial-patellar joints medially rotated in order that the patellae are superimposed to the trochlear grooves and are completely visible in the radiographic image between the trochlear condyles; pelvis in horizontal position looking for the symmetry between the two obturator foramens and the oval pelvic canal. The entire pelvis, femurs and knees should be present on the radiographic image or film.

\section{RESULTS AND DISCUSSION}

The initial scanning of the bones proved to be a fundamental step in the development of the research, allowing to obtain the original digital files of excellent quality and resolution, being possible to distinguish in detail all the bone structures that compose each of the anatomical pieces and their different structures used in the creation of the 3D AMCHD. This finding corroborates the statements of Ugidos Lozano et al. (2018) and Li et al. (2018), which indicate the great effectiveness in the use of the scanner in the digitization of anatomical pieces and their subsequent 3D printing in the creation of anatomical models.

The digital files obtained by scanning the bones in natura followed the same procedure reported by Thomas et al. (2016); in which after the scanning, only minor adjustments were made with the purpose of providing the base model, which did not have any signs of anatomical deformity and allowed to classify it as completely normal or Degree 0 , and is characterized by the correct bone and articular conformation. From the digital files of the base model, the anatomical changes and deformations of the following stages of the disease were generated.

The printed anatomical pieces that compose the base model showed great precision in the replication, in which it was possible to observe that the printed bones maintain the same length, width and thickness of the bones in natura. Furthermore, each of the bone structures was represented in detail. In the hip bone, the acetabulum maintained the depth and the shape of the concavity of the acetabular fossa; the dorsal acetabular edges were perfectly visible and presented the same thickness of the original bone; the obturator foramens maintained the oval shape and symmetry between them, in addition to the other characteristic anatomical structures. In the femur, the head and the neck retained the same soft and defined lines that delimit their parts, besides being possible to perceive the major and minor trochanters, the trochlear condyles and the trochlear groove. The patella preserved its oval shape and the direction of its distal end (Figure 1). 

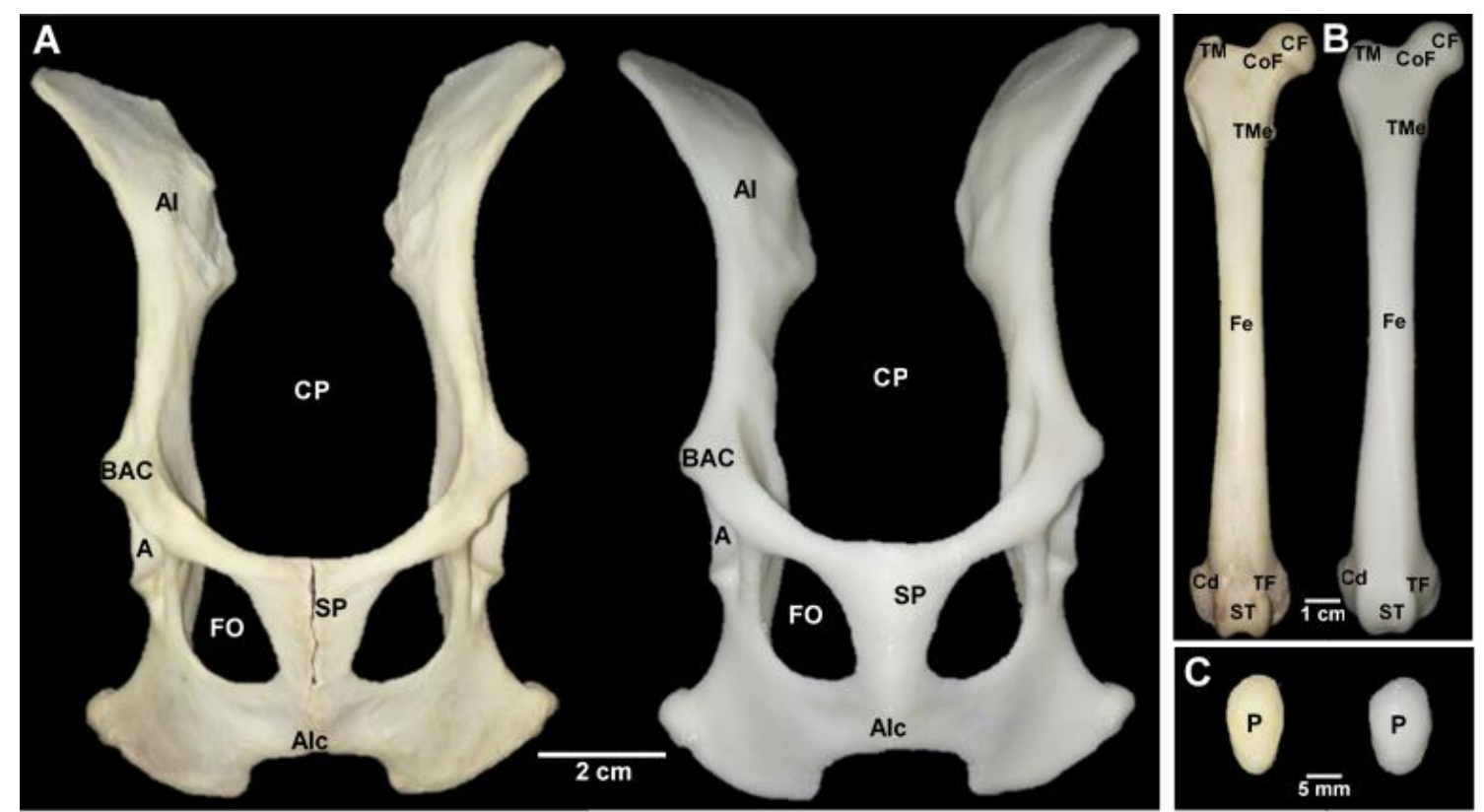

Figure 1. Bones In natura and 3D printing of Dog. A. Hip bone; B. Right femur; C. Patella. AI-Wing of Ilium; CP-Pelvic Canal; BAC-Cranial Acetabular Edge; A-Acetabulum; FO-Obturator Foramen; SPPelvic Symphysis; AIc-Ischial Arch; TM-Major Trochanter; CF-Head of the Femur; CoF-Neck of the Femur; Tme-Minor Trochanter; Fe-Body of the Femur; TF-Femoral Trochlea; Cd-Femoral Condyle; STTrochlear Groove; P-Patella.

After printing the anatomical pieces that conform the base model separately, the latter was assembled preserving its joints using elastic filament and the closure end of the nylon clamps with self-locking closing action at each end of the filament. It was possible to observe the perfect replication of the characteristic movements of the joint (rotation, abduction and adduction), which favored the adoption of adequate radiographic positioning.

For the correct reproduction of the bone deformations required in the replication of the different degrees of CHD, it is fundamental to understand the complexity of the process of creating anatomical models, since there is variation between the model and the real anatomy (Abudayyeh et al., 2017). In this sense, the process of creation of the 3D AMCHD required the complete mastery of the appropriate software for the correct generation of the required deformities, always maintaining the appropriate proportions and preserving bone and structural aesthetics. For the determination of the final costs of printing and the quantity of material used in the manufacture of the 3D AMCHD, the following table (Table 2) is presented.

Table 2 also provides information on the amount of time spent to create each model, taking into account the work done on each bone piece for the correct replication of the disease degrees; from the time required for the scan to the time for replication of the bone and structural deformations consistent with the adopted classification. In determining the economic costs of the 3D AMCHD, the total value for each 1000 grams of ABS thermoplastic filament was US\$ 30.30 , a value obtained from the sum of the values, namely: filament used for the construction of the piece and of the automatically generated structural material and discarded at the end of the printing; values of equipment depreciation and consumption of electricity. 
$3 D$ printing of canine...

Table 2. Parameters of creation and fabrication of the 3D Anatomical Models of Canine Hip Dysplasia

\begin{tabular}{lcccc}
\hline Parts of the 3d amchd & Creation time $(\mathrm{h})$ & Printing time $(\mathrm{h})$ & material used $(\mathrm{g})$ & Cost $(\$)$ \\
\hline Hip bone & 6.0 & 6.5 & 54.77 & 1.75 \\
Right Femur & 4.0 & 3.9 & 36.82 & 1.12 \\
Left Femur & 4.0 & 3.9 & 36.82 & 1.12 \\
Right Patella & 0.5 & 0.2 & 0.88 & 0.03 \\
Left Patella & 0.5 & 0.2 & 0.88 & 0.03 \\
\hline & \multicolumn{5}{c}{ Total } \\
1 3D AMCHD & 15.0 & 14.7 & 130.17 & 4.05 \\
5 3D AMCHD & $60.0^{*}$ & 73.5 & 653.55 & 20.25 \\
\hline
\end{tabular}

(h)-Hours; (g)-grams; (\$)-Dollars; Reference \$ $1.00=\mathrm{R} \$ 3.30$

(*) Creation time applies only to four 3D AMCHD.

In some similar experiments conducted by Watson and Francis (2015), Chung et al. (2018) and $\mathrm{Li}$ et al. (2018), the printing cost values are very similar to the findings of this research (\$4.05 per model). On the other hand, the printing time of the 3D AMCHD (14.7 hours) was higher than the one described by the authors, which is a result of the influence of the printing parameters adopted, such as fine quality and $99 \%$ internal fill, criteria which directly affect the printing speed.

The total time consumed for printing all the 3D AMCHD (73.5 hours) is relatively high. Compared with other manufacturing methods, it should be taken into account that the traditional procedure of production and machining requires firstly the generation of the initial prototypes, from which the final models can be produced, resulting in a higher total time (David Müzel and Alves, 2017). In this sense, it is clear that the time spent for the creation and fabrication of the 3D AMCHD was convenient, since the desired goal was achieved in a short period of time.

The development of the 3D AMCHD started from the need to reproduce the different degrees of CHD severity, mainly to provide a collection of specific anatomical models, which serve as a complementary didactic tool in the Basic and Specialized Medical Education, assisting in the qualification of students and aiming at the familiarization with future anatomopathological findings, enhancing a specific content (McMenamin et al., 2014); in addition to assisting consultation and improving veterinary medical training.
Recently, detailed studies on the pathological morphology of Hip Dysplasia in humans have been developed, mainly in the pathological alterations in the acetabulum and its verification through 3D printing (Cai et al., 2018), which provides current results in this area. However, in the field of Veterinary Medicine it is very difficult to obtain a physical record of the different degrees of CHD, an issue that makes it impossible to have access to the precise material of consultation in the right moment.

In the current market there are different didactic anatomical models available for sale, however, they do not illustrate biological variation and lack pathological authenticity, which may lead to wrong diagnoses and practices in real clinical scenarios (Sugand et al., 2010). In this context, no anatomical models of CHD were found for sale. With the use of 3D printing technology, pelvic deformities can be better evaluated by examining palpable models of the actual bone anatomy. The internal structure was represented as a real-size 3D structure that can be manipulated, rotated and visualized (Hughes et al., 2017), as was done in this research.

Degree 0 was the base model, which had no anatomical deformation sign and no change was made in it (Figure 2A). In Degree I, only minor changes in the articular surface of the Femoral Head and slight changes in the Acetabula were performed, mainly in the Acetabular Fossa, slightly reducing the concavity to achieve the little anatomical incongruity described (Figure 2B). For Degrees II, III and IV, the changes made were deeper in the Head of the Femur, with 
the purpose of being able to replicate the signs of osteoarthrosis corresponding to each degree, besides replicating the flattening of the Cranial Acetabular Edge, according to the classification adopted. The deformations made were necessary to achieve the described dislocation levels, in order to obtain the angles corresponding to each degree of the disease, besides showing macroscopically the corresponding anatomical alterations (Figure 2C, 2D, 2E).
3-D printing is used in combination with medical imaging as a powerful diagnostic tool, making it easier to obtain pathological anatomical models from specialized medical equipment using actual patient image data, favoring a safe and realistic environment for Teaching and training (Marro et al., 2016).

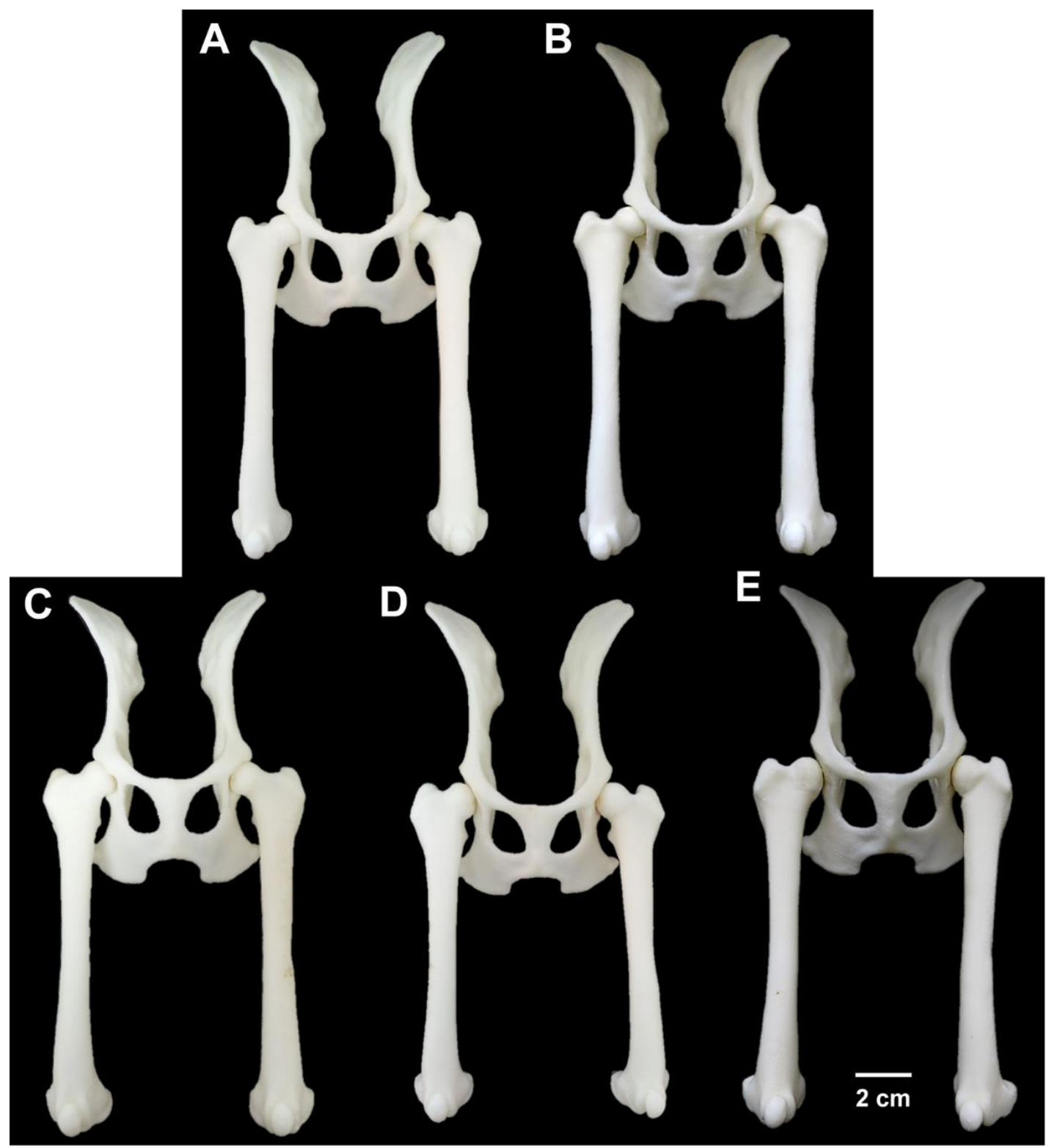

Figure 2. 3D Anatomical Models of Canine Hip Dysplasia. Detail of the macroscopic deformations in the Cranial Acetabular Edges and in the Head and Neck of the Femur. A. Degree 0; B. Degree I; C. Degree II; D. Degree III; E. Degree IV. 
Contrary to what the literature points to regarding the creation of anatomical models from diagnostic images (Eltorai et al., 2015; Liew et al., 2015), the 3D AMCHD provided an unusual and viable situation in the opposite sense of what is recommended, which was to obtain a collection of radiographic images from the models created (Figure 3). The revealed radiographs of the 3D AMCHD show great similarity with regular radiographs, clearly revealing radiopaque and radiolucent regions. In the radiographs, it is possible to observe and determine each of the bones and their corresponding parts, as well as the coxofemoral joints. This allows to replicate the correct standardized positioning for the CHD diagnosis, as well as to allow the accurate determination of the precise points to determine the angles according to Norberg (Figure $3 \mathrm{~A}-\mathrm{E}$ ).
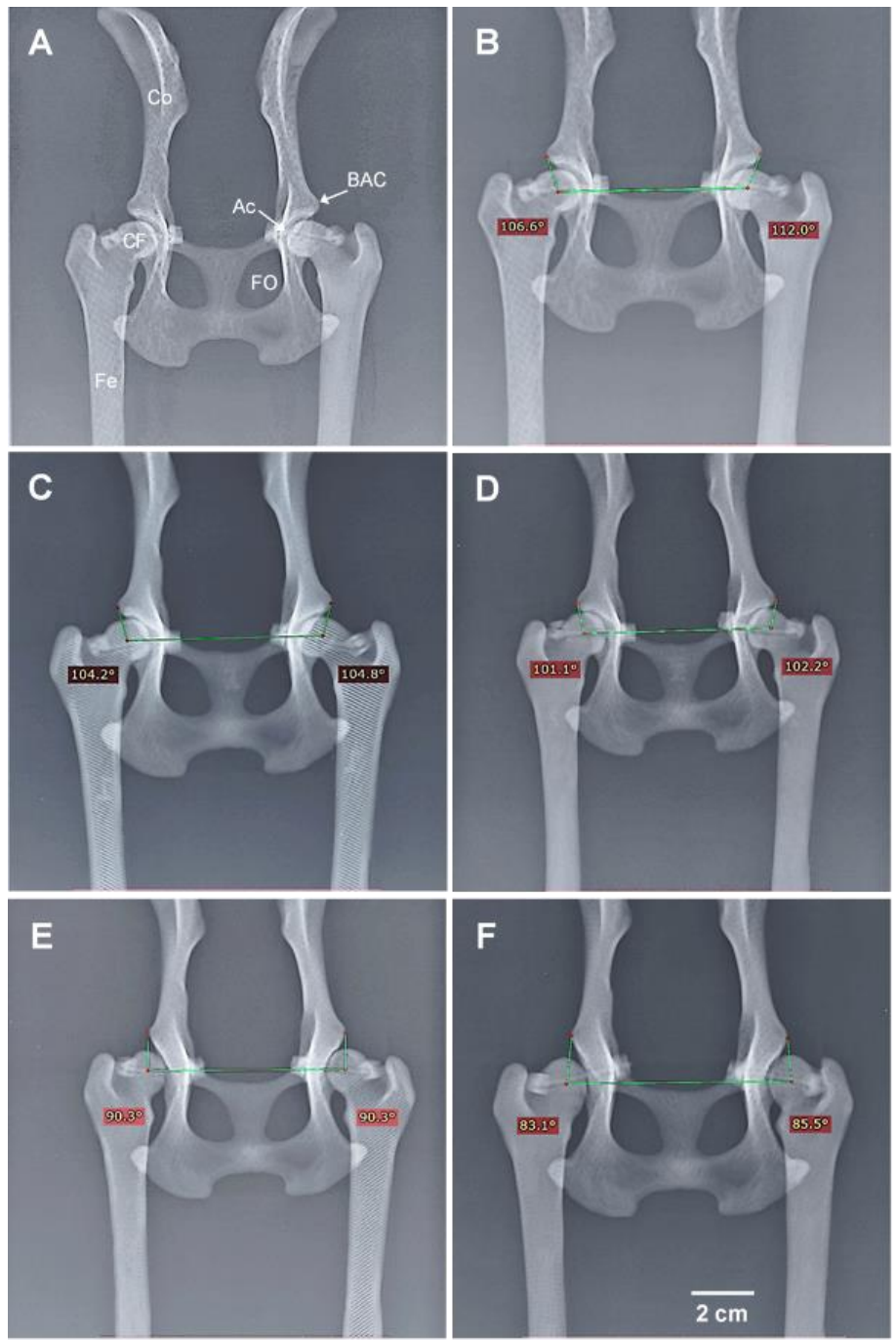

Figure 3. Radiographic images of the 3D Anatomical Models of Canine Hip Dysplasia with their respective angles according to Norberg. A: Detail of the radiograph of the Model. B: Degree 0. C: Degree I. D: Degree II. E: Degree III. F: Degree IV. Co-Hip bone, CF-Femoral Head, Fe-Femur, Ac-Acetabulum, FO-Obturator Foramen, BAC-Cranial Acetabular Edge.

The radiographs of the 3D AMCHD of the different degrees reveal aspects such as: adequate radiographic positioning at all exposures, articular incongruity; levels of dislocation; presence or absence of osteoarthrosis; the signs of anatomical deformity of the involved bone portions; and the respective measured angles (Table 3). 
Table 3. Clinical Signs, Visible Anatomical Changes and Angles Measured According to Norberg of the 3D AMCHD

\begin{tabular}{|c|c|c|c|c|c|c|c|}
\hline \multirow{2}{*}{ Feature } & \multicolumn{7}{|c|}{ Degrees of hip dysplasia } \\
\hline & \multicolumn{2}{|c|}{0} & \multicolumn{2}{|c|}{ I } & II & III & IV \\
\hline $\begin{array}{l}\text { Radiographic } \\
\text { Positioning }\end{array}$ & & & & l & $\checkmark$ & $\checkmark$ & $\checkmark$ \\
\hline Incongruity & & & & Io & Mild & Moderate & Severe \\
\hline Dislocation & & & & lo & Mild & Moderate & Severe \\
\hline Osteoarthrosis & & & & lo & Yes & Yes & Yes \\
\hline $\begin{array}{l}\text { Anatomical } \\
\text { Deformity }\end{array}$ & & & $\begin{array}{l}\text { Mild } \\
\text { articular } \\
\text { of the } \\
\text { head an } \\
\text { acetabu }\end{array}$ & $\begin{array}{l}\text { on the } \\
\text { surface } \\
\text { femoral } \\
\text { d of the } \\
\text { um. }\end{array}$ & $\begin{array}{l}\text { Enlarged and } \\
\text { slightly } \\
\text { compressed } \\
\text { femoral head. } \\
\text { Reduced and } \\
\text { short femoral } \\
\text { neck. } \\
\text { Reduced } \\
\text { acetabulum. } \\
\text { Rounded and } \\
\text { slightly reduced } \\
\text { cranial } \\
\text { acetabular edge. }\end{array}$ & $\begin{array}{l}\text { Short and } \\
\text { straight } \\
\text { femoral } \\
\text { neck. } \\
\text { Small and } \\
\text { flat femoral } \\
\text { head. } \\
\text { Concavity of } \\
\text { the } \\
\text { acetabulum } \\
\text { almost } \\
\text { disappears. } \\
\text { Worn and } \\
\text { blunt cranial } \\
\text { acetabular } \\
\text { edge. }\end{array}$ & $\begin{array}{l}\text { Acetabular } \\
\text { wear. } \\
\text { Cranial } \\
\text { acetabular } \\
\text { edge almost } \\
\text { absent. } \\
\text { Straight } \\
\text { femoral } \\
\text { neck. } \\
\text { Small, flat } \\
\text { and short } \\
\text { femoral } \\
\text { head. }\end{array}$ \\
\hline Expected angle & & & & $05^{\circ}$ & $\geq 100^{\circ}$ & $\geq 90^{\circ}$ & $<90^{\circ}$ \\
\hline Obtained angle & $\begin{array}{l}\mathrm{RIG} \\
106.6^{\circ}\end{array}$ & $\begin{array}{c}\mathrm{LEF} \\
112.0^{\circ}\end{array}$ & $\begin{array}{c}\text { RIG } \\
104.2^{\circ}\end{array}$ & $\begin{array}{c}\text { LEF } \\
104.8^{\circ}\end{array}$ & $\begin{array}{cc}\text { RIG } & \text { LEF } \\
101.1^{\circ} & 102.2^{\circ}\end{array}$ & $\begin{array}{cc}\mathrm{RIG}^{\circ} & \mathrm{LEF} \\
90.3^{\circ} & 90.3^{\circ}\end{array}$ & $\begin{array}{cc}\text { RIG } & \text { LEF } \\
83.1^{\circ} & 85.5^{\circ}\end{array}$ \\
\hline
\end{tabular}

$(\checkmark)$-Adequate; RIG-Right; LEF-Left.

Anatomical models offer future veterinarians an alternative to learn of the disease, since they allow the complete manipulation of the model for the correct interpretation of the studied structure, as well as of the spatial relations with the adjacent tissues (Ballard et al., 2017). Hence the importance of the radiological evaluation made for each 3D AMCHD to prove the angle advocated by the FCI in determining the severity of the disease, in which it was clearly demonstrated that $3 \mathrm{D}$ printing is capable of reproducing the cortical bone region of the models, the same as in the study carried out by Inzunza et al. (2015).

This collection of radiographic images of the 3D AMCHD will allow Veterinary Hospitals and Clinics, as well as the Diagnostic and Professional Training Center, to have access to all the different degrees of the disease for consultation, thereby providing a reference for medical reports and better training of future professionals.

\section{CONCLUSIONS}

The study confirms the possibility of reproducing the different anatomopathological variations that characterize the different degrees of Canine Hip Dysplasia. With the creation of the 3D AMCHD, each of the representative degrees of the disease is available, which classifies the severity of the disease, making it easier for veterinary students and professionals to look, touch, rotate, measure and manipulate the representative anatomical models and become familiar with the macroscopically visible anatomical and pathological aspects, as well as being able to evaluate the anatomy of the region. In addition, the 3D AMCHD allow to obtain radiographic images of excellent quality that faithfully represent the structural conformation of the coxofemoral joint. 


\section{ACKNOWLEDGMENTS}

This study was financed (Grant term n.26/2018 PPP-FAPAC/CNPq - Brazil). To the Partnerships Program for Education and Training (PAEC) through the Organization of American States (OAS) and the Coimbra Group of Brazilian Universities (GCUB). To the Coordination for the Improvement of Higher Education Personnel (CAPES).

\section{REFERENCES}

ABUDAYYEH, I.; GORDON, B.; ANSARI, M.M. et al. A Practical guide to cardiovascular 3D printing in clinical practice: overview and examples. J. Interv. Cardiol., v.31, p.375-383, 2017.

BALLARD, D.H.; TRACE, A.P.; ALI, S. et al. Clinical applications of 3D printing: primer for radiologists. Acad. Radiol., v.24, p.1-14, 2017.

CAI, Z.; ZHAO, Q.; ZHANG, L. et al. Can Computed tomography accurately measure acetabular anteversion in developmental dysplasia of the hip? Verification and Characterization using 3D printing technology. $J$. Pediat. Orthop., v.38, p.1-6, 2018.

CHUNG, M.; RADSCI, N.; ROBERT, C. et al. On the optimization of low - cost FDM 3D printers for accurate replication of patient - specific abdominal aortic aneurysm geometry. 3D Print. Med., v.4, p.1-2, 2018 .

DAVID MÜZEL, S.; ALVES, M. Estudo da usinagem dos compósitos plástico madeira e madeira plástica. 2017. 161f. Dissertação (Mestrado) - Faculdade de Engenharia de Guaratinguetá, Universidade Estadual Paulista, Guaratinguetá, SP.

ELTORAI, A.E.M.; NGUYEN, E.; DANIELS, A.H. Three - dimensional printing in orthopedic surgery. Orthopedics, v.38,p.684-687, 2015.

FLÜCKIGER, M. Scoring Radiographs for canine hip dysplasia - the big three organizations in the world. Eur. J. Comp. Anim. Pract., v.17, p.135-140, 2007.

HUGHES, A.J. DEBUITLEIR, C.; SODEN, P. et al. 3D Printing aids acetabular reconstruction in complex revision hip arthroplasty. Adv. Orthop., v.2017, p.7, 2017.

INZUNZA, O.; CARO, I.; MONDRAGÓN, G. et al. Impresiones 3D, nueva tecnologia que apoya la docencia anatómica. Int. J. Morphol., v.33, p.11761182, 2015.
JANSSENS, L.; DE RIDDER, M.; VERHOEVEN, G.; GIELEN, I. et al. Comparing Norberg angle, linear femoral overlap and surface femoral overlap in radiographic assessment of the canine hip joint. $J$. Small Anim. Pract., v.55, p.135-138, 2013.

LI, F.; LIU, C.; SONG, X. et al. Production of accurate skeletal models of domestic animals using three-dimensional scanning and printing technology. Anat. Sci. Educ., v.11, p.73-80, 2018.

LIEW, Y.; BEVERIDGE, E.; DEMETRIADES, A.K. et al. 3D pringting of patient - specific anatomy: A tool to improve patient consent and enhance imaging interpretation by trainees. Br. J. Neurosurg., v.29, p.13, 2015 .

LIM, K.H.A.; LOO, Z.Y.; GOLDIE, S.J. et al. Use of 3D printed models in medical education: a randomized control trial comparin 3D prints versus cadaveric materials for learning external cardiac anatomy. Anat. Sci. Educ., v.9, p.213-221, 2016.

MARRO, A.; BANDUKWALA, T.; MAK, W. Three dimensional printing and medical imaging: a review of the methods and applications. Curr. Probl. Diag. Radiol., v.45, p.2-9, 2016.

MCMENAMIN, P.G.; QUAYLE, M.R.; MCHENRY, C.R. et al. The production of anatomical teaching resources using three-dimensional (3D) printing technology. Anat. Sci. Educ., v.7, p.1-8, 2014.

SCHACHNER, E.R.; LÓPEZ, M.J. Diagnosis, prevention and management canine hip dysplasia: a review. Vet. Med. Res. Rep., v.2015, p.181-192, 2015.

SOO, M.; WORTH, A.J. Canine hip dysplasia: phenotypic scoring and the role of estimated breeding value analysis. N.Z. Vet. J., v.63, p.69-78, 2015.

SUGAND, K.; ABRAHAMS, P.; KHURANA, A. The anatomy of anatomy: a review for its modernization. Anat. Sci. Educ., v.3, p.83-93, 2010.

THOMAS, D.B.; HISCOX, J.D.; DIXON, B.J. et al. 3D scanning and printing skeletal tissues for anatomy education. J. Anat., v.229, p.473-481, 2016.

UGIDOS LOZANO, M.T.; BLAYA HARO, F.; RUGGIERO, A. et al. Different digitalization tecniques for 3D printing of anatomical pieces. J. Med. Syst., v.42, p.42-46, 2018.

WATSON, C.M.; FRANCIS, G.R. Three dimensional printing as an effective method of producing anatomically accurate models for studies in thermal ecology. J. Thermal Biol., v.51, p.42-46, 2015. 